Kayman, F. ve Aydın, E. (2021). Ömer Seyfettin'in And adlı eserinde yer alan şiddet olgusuna ilişkin öğrenci görüşleri. Ana Dili Eğitimi Dergisi, 9(2), 416-429.

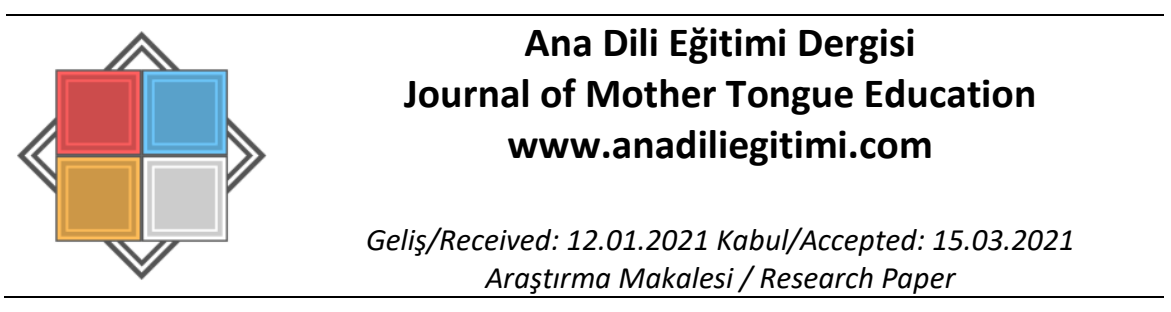

\title{
Ömer Seyfettin'in And Adlı Eserinde Yer Alan Şiddet Olgusuna İlişkin Öğrenci Görüşleri
}

\author{
Faruk KAYMAN* \\ Erkan AYDIN**
}

\begin{abstract}
Öz
Bu araştırmanın amacı, ortaokul 6. sınıf öğrencilerinin Ömer Seyfettin'in And adlı öyküsünde yer alan şiddet olgusu hakkındaki görüşlerini tespit etmektir. Araştırma, Tuşba Kaymakamlık makamından araştırma izni alındıktan sonra 2021 yılı Ocak ayında gerçekleştirilmiştir. Araştırmanın örneklemini, Van ili Tuşba ilçesine bağlı İsmail Hakkı Tonguç Ortaokulu 6-A sınıfında öğrenim gören 22 öğrenci oluşturmaktadır. Araştırmada nitel araştırma desenlerinden fenomenoloji (olgubilim) kullanılmıştır. Verilerin toplanmasında uzman görüşü alınarak geliştirilen ve açık uçlu sorulardan oluşan yarı yapılandırılmış görüşme formu kullanılmış, verilerin çözümlenmesinde ise içerik analizi yöntemine başvurulmuştur. Araştırma sonucunda öğrencilerin eserde yer alan şiddet sahnelerini beğenmedikleri, şiddet içeren bölümlerden etkilendikleri, bu bölümleri eserden çıkarmak istedikleri tespit edilmiştir.
\end{abstract}

Anahtar Kelimeler: Ömer Seyfettin, And, şiddet olgusu, öğrenci görüşü

\section{Student Opinions on the Phenomenon of Violence in Ömer Seyfettin's Work titled And Abstract}

The purpose of this study was to determine the opinions of middle school $6^{\text {th }}$ grade students about the phenomenon of violence in Ömer Seyfettin's story titled And. The research was carried out in January 2021 after receiving permission from the Tuşba District Governorship. The sample consisted of 22 students studying in the 6-A section in the İsmail Hakkı Tonguç Secondary School in the Tuşba district of the Van province. Phenomenology, a qualitative research design, was used in the study. A semi-structured interview form, consisting of open-ended questions and developed in the light of expert opinion, was used for data collection. Content analysis was used in data analysis. The results showed that the students did not like the scenes of violence in the story, that they were affected by those scenes, and that they wanted to remove those parts from the story.

Keywords: Ömer Seyfettin, And, phenomenon of violence, student opinion

\section{Giriş}

Çocuk edebiyatı eserlerinin çocuğun gelişimine önemli ölçüde katkı sunması, onlara okuma sevgisi ve alışkanlığı kazandırması, ileride karşılaşmaları muhtemel olaylar ve kişiler hakkında tecrübe kazanmalarına yardımcı olması beklenmektedir. Çocuğun ilgisini, intiyaçlarını, bakış açısını, dil ve anlam evrenini ön planda tutan, kısacası çocuk gerçekliğine ve çocuğa görelik ilkesine uygun bir edebî eserde hangi konuların işlenmesi gerektiği hususu son yıllarda sürekli tartışılan bir konu olarak ön plana çıkmaktadır.

Çocuğun okuyabileceği kitaplar ve bu kitaplarda yer alan konular onun yaş grubuna göre değişebilmektedir. Bu nedenle çocuklara okutulacak veya tavsiye edilecek kitaplarda onların yaş grupları göz önünde bulundurulmalı, merak ettikleri ve ilgi duydukları dünyanın yetişkinlerin dünyasından farklı olduğu unutulmamalıdır. Neydim (2003), çocuk okura kitap seçerken "öncelikle

\footnotetext{
${ }^{*}$ Dr., Milli Eğitim Bakanlığı, Van, farukkayman@gmail.com, ORCID: orcid.org/0000-0002-7917-7188

${ }^{* *}$ Dr., Milli Eğitim Bakanlığı, Adıyaman, erkanaydin02@gmail.com, ORCID: orcid.org/0000-0002-6452-6058
} 
onun yaşını, duygu dünyasını, kültürel art alanını ve birikimini, yaşam deneyimlerini, kaygılarını, korkularını, umutlarını, kafasındaki soruları ve sorunları, arayışlarını, çıkmazlarını bilmekle yükümlü" olduğumuzu ifade etmekte, belli bir yaştan sonra çocuğun da kitap seçiminde söz sahibi olması gerektiğini belirtmektedir.

\section{Çocuk Kitaplarında Çocuğa Görelik ilkesi}

Çocuk kitaplarının çocuk gerçekliğine uygun olmasının yanı sıra çocuğa göre olması da önem taşımaktadır. Bu kitapların; çocuğun hayal dünyasına seslenmesi, dil ve anlatım bakımından onun anlayabileceği ve zevk alabileceği bir düzeyde olması, sevebileceği ve ilgi duyabileceği konulara yer vermesi, onu duygu ve düşünce yönünden beslemesi, kurgusu ve olay örgüsünün karmaşık olmaması, çocuğun dikkatini dağıtacak ayrıntılardan uzak olması (Yurttaş, 1997 ) beklenmektedir. Bir çocuk kitabının çocuğa göre olabilmesi için çocuk duyarlılı̆̆ını başarıyla yansıtabilmesi ve çocuk kalbinin duyarlılıklarıyla bütünleşmesi (Şirin, 1998) gerekmektedir.

Çocuk kitaplarının çocuğa görelik ilkesine uygunluğu; o kitapların biçimsel, eğitsel ve içerik özelliklerine bakılarak değerlendirilmektedir. Bir çocuk kitabı biçimsel açıdan değerlendirilirken o kitabın kapağı, boyutu, ciltleme şekli, sayfa düzeni, kâğıt türü, harf karakteri ve büyüklüğü ve kitapta kullanılan resimler göz önünde bulundurulmaktadır. Bu özellikler çocuğun kitaplara karşı ilgi duyabilmesi ve kitaplarla sağlam bir ilişki kurabilmesi bakımından oldukça önemlidir(Çer, 2014). Bu bakımdan çocuk kitaplarının tasarımı, çocukları okumaya isteklendirecek bir anlayışla yapılmalıdır (Sever, 2008). Çocuk kitaplarının eğitsel açıdan da çeşitli özelliklere sahip olması gerekmektedir. Bu kitaplarda çocuk özne konumunda olmalı (Şirin, 2007); öğüt verici, öğretici bir anlayışın; korku, kaygı ve şiddetin; ideolojik ve aşırı duygusal söylemlerin; tek ve değişmez doğruların yer almaması gerekmektedir. Aksi hâlde çocuk kitapları, çocukta duygusal örselenmelere yol açabilir; korku, kaygı ve şiddetten kaynaklanan ruhsal tahribat oluşturabilir; onu, şiddeti olumlayan, hayata değişmez doğrularla bakan, eleştirel ve yaratıcı düşünceden yoksun biri hâline getirebilir (Dilidüzgün, 2003; Sever, 2008; Uçan, 2005; Köksal, 1997).

Çocuk kitaplarının biçimsel ve eğitsel özelliklerinin yanında içerik özellikleri bakımından da başarıı olması gerekmektedir. Bir çocuk kitabı, biçimsel açıdan ne kadar başarılı olursa olsun içerik bakımından yetersiz veya başarısızsa bu eserin çocuklara faydalı olması beklenemez (Oğuzkan, 2006). Çocuk kitaplarının içerik özellikleri içinde konu önemli bir yer tutmaktadır. Bu kitaplarda işlenmesi gereken konuların neler olabileceği hususunda iki farklı görüşün olduğunu söylemek mümkündür (Yılmaz ve Yakar, 2018). ilki bu kitaplarda sevgi, mutluluk, iyilik, yardımseverlik gibi hayatın olumlu yönlerinin konu edinilmesi gerektiğini savunan görüştür (Yalçın ve Aytaş 2008; Öztürk ve Giren 2016). Bu görüşü savunanlara göre çocuğun ruh sağlığını olumsuz etkileyecek, hayatın olumsuz taraflarını gösteren şiddet, ölüm, akran zorbalığı, engellilik, ayrılık gibi travmatik konuların çocuk kitaplarında yer bulması doğru değildir ve bu konular aşamalı bir şekilde ileriki yaşlarda okurlara sunulmalıdır. Diğer görüşte olanlar ise çocuğun günlük hayatta karşılaşabileceği her hadisenin veya durumun çocuk kitaplarının konusu olabileceğini savunmaktadırlar (Fırat ve Çeker 2016; Moustakis, 1982). Bu görüşte olanlar konudan ziyade konunun çocuğa sunuluş şeklinin önemli olduğunu düşünmektedirler.

Günümüzde çocuğun birçok toplumsal sorunla karşılaştığını ifade eden Dilidüzgün (1996: 64), çocukların bu sorunlardan etkilendiğini, bu sorunlara şahit olduğunu belirttikten sonra bu durumun çocuk edebiyatında bu tür sorunlara yer vermeyi zorunlu kıldığını söylemiştir. Öte taraftan kendi sorunlarına ve içinde bulunduğu dünyaya yakın bir dünyayı çocuk kitaplarında bulmanın çocuklar için hazır bir reçete anlamı taşımadığını söyleyen Dilidüzgün'e göre önemli olan, okurun bilinçlenmesi ve benzer gerçeklerin farkı bir dille ona sunulmuş olmasıdır (s. 97). Böylelikle çocuk okur, bu eserler vasıtasıyla deneyim kazanacak ve karşılaşabileceği muhtemel sorunlar karşısında sağlıkı bir ruh hâli edinebilecektir.

\section{Çocuk Kitaplarında Şiddet Teması}

Hem yerli hem de yabancı literatür incelendiğinde, çocuk kitaplarında yer alan ve üzerinde tartışılan konulardan biri de şiddettir. Yukarıda bahsi geçen travmatik konularda ortaya çıkan iki görüşün şiddet konusunda da geçerli olduğunu söylemek mümkündür. Birinci görüşü savunanlar bu 
eserlerde hiçbir şiddet ögesinin olmaması gerektiğini düşünmekte ve şiddet içeren ifadeleri çocuk okur için risk olarak değerlendirmektedirler (Dağlığlu ve Çamlıbel Çakmak, 2009; Öztürk ve Giren, 2016; Yalçın ve Aytaş, 2008). Diğer görüşe göre ise çocuk okurun ruh sağlığını gözetmek ve konunun sunuluş şekline dikkat etmek kaydıyla diğer travmatik konular gibi şiddet olgusu da çocuk kitaplarında yer alabilir. Zira çocuk neredeyse her gün bizzat veya kitle iletişim araçları vasıtasıyla şiddete şahit olmakta ve bu olguyu hayatın bir gerçeği olarak yaşamaktadır. Bu görüşü savunanlar şiddet olgusunun görmezden gelinmesini ve bu olguya çocuk kitaplarında yer verilmemesini doğru bulmamaktadırlar (Erdal, 2009; Fırat ve Çeker, 2016; Moustakis, 1982; Nimon, 1993; Yılmaz, 2016). Hayatın içinde var olan şiddetin çocuk kitaplarında yer alabileceğini ifade eden Sever (2008: 118), önemli olanın çocuğun bu kitaplar vasıtasıyla şiddetle nasıl baş edilmesi gerektiğini algılamasıdır. Şiddetin bu eserlerdeki sunuluş şekli üzerinde duran Sever (2002: 36), çocuğu duygusal örselenmelerden korumak için eserde kahramanın amacına şiddet kullanarak ulaşmaması gerektiğini ifade etmektedir. Ona göre bu eserlerde şiddet olumlanmamalı ve çocuk okura bir çözüm yolu olarak sunulmamalıdır.

Türk edebiyat tarihinde önemli bir yere sahip olan Ömer Seyfettin'in yaşadığı dönemin koşulları gereği öykülerinde şiddete çokça yer verdiği görülmektedir. Çocuklar için yazmamasına rağmen eserleri çocuk okurlar tarafından sıkça okunan (Fırat, 2014; İsen-Durmuş, 2011; Tosunoğlu, Haktanır, Çocuk ve Gök, 2008), öğretmenler tarafından en çok bilinen ve öğrencilere tavsiye edilen yazarların başında gelen (Büyükkavas Kuran ve Ersözlü, 2009) Ömer Seyfettin'in şiddet içeren eserleri çok sayıda araştırmacı tarafından incelenmiştir (Akkaya, 2003; Aktaş ve Uzuner Yurt, 2017; Bölükbaş, 2003; Cengiz, 2011; Turan, 2006). Bu çalışmaların büyük bir kısmında şiddet içeren eserler çocuk edebiyatının temel ilkeleri bağlamında ele alınmış, çocuğa uygun olup olmadığı üzerinde çeşitli değerlendirmelerde bulunulmuştur.

Yapılan bu çalışmaların yanında konunun öznesi olan çocukların verimli bir okuma gerçekleştirmelerini sağlamak ve ruhsal tahribat yaşamalarını önlemek için uygulamalı çalışmalar yaparak bahsi geçen eserlerde yer alan şiddet olgusu hakkında neler düşündüklerini tespit etmek büyük önem taşımaktadır. Kayman (2020), Ömer Seyfettin'in şiddet içeren eserleri üzerine uygulamalı bir çalışma yapmıs, bu eserler hakkında çocuk okurların tepkilerini tespit etmeye çalışmışır. Yapılan bu uygulamalı çalışmada And adlı eserin yer almadığı görülmüştür. And adlı eser ile ilgili uygulamalı bir çalışmanın yapılmaması ve eserde şiddet sahnelerine yer verilmesi bu çalışmada bu eserin tercih edilmesine neden olmuştur. Eser, öğrenciler tarafından okunduktan sonra şiddet sahneleri hakkında neler düşündükleri belirlenmeye çalışılmıştır. Çocuk okurun şiddet olgusu hakkındaki düşüncelerinin ortaya konulmasının; çocuk edebiyatı yazarlarına, anne babalara, öğretmenlere ve eğitimin tüm paydaşlarına katkı sağlayacağı düşünülmektedir.

\section{Araştırmanın Amacı}

Bu araştırmanın amacı, ortaokul 6. sınıf öğrencilerinin Ömer Seyfettin'in "And" adlı öyküsünde şiddet içeren bölümler hakkındaki görüşlerini tespit etmektir. Bu amaç doğrultusunda, "Ortaokul 6. sınıf öğrencileri, Ömer Seyfettin'in And adlı öyküsünde yer alan şiddet sahneleri hakkında neler düşünmektedir?" sorusuna cevap aranmıştır.

\section{Araştırmanın Modeli}

\section{Yöntem}

Bu araştırma nitel olarak desenlemiştir. "Nitel araştırma; gözlem, görüşme, doküman analizi gibi nitel veri toplama yöntemlerinin kullanıldığı, algıların ve olayların doğal ortamda gerçekçi ve bütüncül bir biçimde ortaya konmasına yönelik nitel bir sürecin izlendiği araştırma olarak tanımlanabilir" (Yıldırım ve Şimşek, 2016: 41). Aynı zamanda araştırmada, nitel araştırma desenlerinden olgubilim (fenomenoloji) deseni kullanılmıştır. Bu desen, bir olguyla ilgili bireylerin deneyimlerinin betimlendiği bir araştırma desenidir (Creswell, 2017). Araştırmada bu desenin kullanılma nedeni, öğrencilerin okuduklarından yola çıkılarak deneyimleriyle bir olguyu betimlemelerini sağlamaktır. 


\section{Örneklem / Araştırma grubu}

Araştırmanın çalışma grubunu, Van ili Tuşba ilçesine bağlı İsmail Hakkı Tonguç Ortaokulunda öğrenim gören 6. sınıf öğrencileri oluşturmaktadır. Araştırmaya 6. sınıflardan 10 kız, 12 erkek olmak üzere toplam 22 öğrenci katılmıştır. Araştırmada; bulundukları yaş düzeyi itibariyle hassas bir dönemde olmaları nedeniyle amaçlı örneklem yöntemi kullanılarak 6. sınıf öğrencileri seçilmiştir. Zira Yavuzer (1987: 116), araştırma grubundaki öğrencilerin de içinde bulunduğu son çocukluk dönemindeki çocuklar için şunları ifade etmektedir: "Son çocukluk döneminde, aşırı duyarlılı̆ın yanında görülen bir diğer özellik de kolay etkilenmedir. Bu dönemdeki çocuklar, kendi arzularının diğer çocukların doğrultusunda olduğu inancındadırlar. Bu da onların gruba kabul edilmelerini kolaylaştırır. Yaşam süreci içinde, belki de hiçbir dönemde rastlanamayacak düzeydeki kolay etkilenme bu evrede görülür." Amaçlı örneklem seçkisiz olmayan bir örnekleme yöntemidir. Bu yöntem, çalışmanın amacına uygun bir şekilde bilgi açısından zengin durumların seçilerek derinlemesine araştırma yapılmasını sağlar (Büyüköztürk vd., 2016). Yol, maliyet ve zaman gibi unsurlar da göz önünde bulundurulmuş ve kolay ulaşılabilir örneklem yöntemi kullanılarak İsmail Hakkı Tonguç Ortaokulu uygulama okulu olarak seçilmiştir.

\section{Veri Toplama Araçları}

Uygulama sonrasında öğrencilerin görüşlerini tespit etmek için araştırmacılar tarafından yarı yapılandırmış görüşme formu hazırlanmış, görüşme formunda yer alan soruların amacına uygun olup olmadığını belirlemek amacıyla Türkçe eğitimi alanında uzman iki öğretim üyesinin görüşüne başvurulmuştur. Uzman görüşleri neticesinde sorulara son hali verilmiş ve çalışmada kullanılmıştır. Görüşme formu iki bölümden oluşmaktadır. Birinci bölümde öğrencilere adları, soyadları, sınıfları ve cinsiyetleri gibi kişisel bilgileri sorulmuştur. İkinci bölümde ise; öğrencilerin eseri beğenip beğenmedikleri, kitapta dikkatlerini en çok çeken şeyin ne olduğu, eserde değiştirmek istedikleri herhangi bir şeyin olup olmadığı, kitapta çocukların kan kardeş olma biçimleriyle ilgili ne düşündükleri, kitaptaki kahramanlardan biri olan Mıstık’ın ölüm şekli hakkındaki düşünceleri, köpeğin kovalanması ve dövülmesi hakkındaki görüşleri, kitabın kapağında yer alan resmi nasıl yorumladıkları ile ilgili 7 açık uçlu soru bulunmaktadır.

\section{İşlem / Verilerin Toplanması}

Uygulama, uzaktan eğitim sürecinde bulunan 6. sınıf öğrencileriyle yapılmıştır. Uygulama sürecinde öğrencilere, Türkçe Öğretmenleri ve velileriyle iletişim halinde Ömer Seyfettin'in And adlı eseri okutulmuştur. Daha sonra yarı yapılandırılmış görüşme formu kullanılarak öğrencilerin kitapla ilgili görüşleri alınmıştır. Öğrencilerin yazııı ifadelerinden elde edilen veriler incelenerek anlaşılmayan veya kapalı kalan bölümler, araştırmacı tarafından öğrenci velisi aranarak öğrenciye sorulmuştur.

\section{Verilerin Analizi}

Araştırmada, yarı yapılandırılmış görüşme formlarından elde edilen verileri analiz etmek amacıyla nitel analiz yöntemlerinden içerik analizi kullanılmıştır. "içerik analizi, belirli kurallara dayalı kodlamalarla bir metnin bazı sözcüklerinin daha küçük içerik kategorileriyle özetlendiği, sistematik yinelenebilir bir teknik olarak tanımlanır" (Büyüköztürk, vd. 2016: 240). İçerik analizinde görüşme, gözlem veya dokümanlar aracılığılla elde edilen nitel veriler; verilerin kodlanması, temaların bulunması, kod ve temaların düzenlenmesi, bulguların tanımlanması ve yorumlanması şeklinde dört aşamada analiz edilmektedir (Yıldırım ve Şimşek, 2016). Bu araştırmada da öğrencilerin görüşleri incelenmiş, kodlanmış, bu kodlardan kategoriler oluşturulmuştur. Oluşan kategoriler çeşitli temalar altında sınıflandırılmıştır.

\section{Geçerlik ve Güvenirlik}

Araştırmada, öğrencilerin görüşleri listelenerek iki kodlayıcı tarafından kodlar çıkarılmış ve buna bağlı olarak kategoriler oluşturulmuştur. Daha sonra bu kategoriler tablo haline getirilmiş ve elde edilen verilerle bulgular tanımlanarak yorumlanmıştır. Araştırmanın güvenirliği için Miles ve Huberman'ın (1994) formülü (görüş birliği/ görüş birliği + görüş ayrılığı) kullanılarak kodlayıcılar arası 
güvenirlik katsayısı birinci soruda \%94, ikinci soruda \%89, üçüncü soruda \%92, dördüncü soruda 92, beşinci soruda \%90, altıncı soruda \%92, yedinci soruda \%94 olarak hesaplanmıştır.

\section{Araştırma ve Yayın Etiği}

Bu çalışmada "Yükseköğretim Kurumları Bilimsel Araştırma ve Yayın Etiği Yönergesi" kapsamında uyulması belirtilen tüm kurallara uyulmuştur. Yönergenin ikinci bölümü olan "Bilimsel Araştırma ve Yayın Etiğine Aykırı Eylemler" başlığı altında belirtilen eylemlerden hiçbiri gerçekleştirilmemiştir. Çalışmada öğrenci velilerinden izin alınmış, onlara bilgilendirilmiş gönüllü olur/onam formu imzalatılmıştır.

\section{Etik Kurul izni}

Kurul adı = Van ili Tuşba İlçe Milli Eğitim Müdürlüğü

Karar tarihi $=06 / 01 / 2021$

Belge sayı numarası $=18856386$

\section{Bulgular}

Ömer Seyfettin'in "And" adlı eserindeki şiddet olgusuna yönelik öğrencilere çeşitli sorular sorulmuş ve öğrencilerin eserde geçen olaylar hakkında şiddetle alakalı düşünceleri analiz edilmiştir. Bu bağlamda, öncelikle öğrencilere eseri beğenip beğenmedikleri ve bunun nedeni hakkında sorular sorulmuştur. Öğrencilerin cevaplarından hareketle kategoriler oluşturulmuş ve Tablo 1'e yansıtılmıştır.

Tablo 1.

Öğrencilerin "And" adlı eseri beğenme durumlarıly ilgili görüşleri

\begin{tabular}{llcc}
\hline Öğrenci Görüşleri & & $\mathrm{f}$ & $\%$ \\
\hline \multirow{3}{*}{ Beğendim } & Mutlaka okunmalı & 5 & 9,80 \\
& Güzel & 3 & 5,88 \\
& Okunabilir & 2 & 3,92 \\
\hline \multirow{3}{*}{ Beğenmedim } & Okunmamalı & 13 & 25,49 \\
& Güzel değil & 9 & 17,65 \\
& Kötü & 8 & 15,69 \\
& Korkunç & 6 & 11,76 \\
& Acıklı & 5 & 9,80 \\
\cline { 2 - 4 } & Toplam & 51 & 100 \\
\hline
\end{tabular}

Tablo 1 incelendiğinde, sorulan sorulardan "beğendim" ve "beğenmedim" şeklinde iki kategorinin oluştuğu görülmektedir. Beğendim kategorisine yönelik mutlaka okunmalı $(\% 9,80)$, güzel $(\% 5,88)$, okunabilir $(\% 3,92)$ şeklinde alt kategoriler elde edilmiştir. Beğenmedim kategorisine yönelik ise okunmamalı $(\% 25,49)$, güzel değil $(\% 17,65)$, kötü $(\% 15,69)$, korkunç $(\% 11,76)$, acıklı $(\% 9,80)$ şeklinde beş alt kategori elde edilmiştir. Toplam dağıııma bakıldığında, "beğendim" diyen öğrencilerin oranı \%19,61; beğenmedim diyen öğrencilerin oranı ise \%80,39 olarak tespit edilmiştir. Veriler incelendiğinde, öğrencilerin çoğunluğunun eseri beğenmemiş olduğu söylenebilir. Bu bağlamda bazı öğrencilerin cevapları şöyledir:

Beğenmedim, tavsiye etmem. Bazı korkunç şeyler var (Ö16).

Kitap güzel değildi. Sonu kötüydü bence okunmamalı çünkü sonu saçma geldi bana (Ö18).

Bence güzel değildi ben beğenmedim başkalarının okumasını istemiyorum çünkü içinde bazı korkutucu şeyler var (Ö15).

Kitap fazla kötü ve acıklı bir hikâyeydi. Okunmasını tavsiye etmem (Ö8).

Kitap bence çok güzel, ben çok beğendim. Bence başkaları da okumalı. Ben çok beğendim, eminim ki başkaları da sever. (Ö20).

Öğrencilerin görüşlerinden yola çıkılarak şu sonuçlar çıkarılabilir. Öğrenciler, kitabı kötü ve korkunç buldukları için kitabın başkaları tarafından okunmasını istememektedirler. Öğrencilerin kitapla 
ilgili olumsuz görüşlerinin sebebinin kitapta geçen olayların öğrencileri kötü etkilemiş olmasından kaynaklandığı söylenebilir. Ayrıca eser, öğrencilerde olumsuz hisler uyandırdığı için onların okunmamalı, korkunç, acıklı gibi ifadeler kullanmalarına neden olmuştur. Çok az öğrencinin ise kitabı beğendiği, bundan dolayı da başkalarının okuması için tavsiye ettiği görülmektedir.

Öğrencilerin eser hakkındaki şiddet algısını belirlemek ve daha çok hangi olaylardan etkilendiklerini belirlemek amacıyla "Kitapta dikkatinizi çeken olay nedir? Niçin?" soruları sorulmuştur. Bu doğrultuda öğrencilerin verdiği cevaplardan hareketle Tablo 2 oluşturulmuştur.

Tablo 2.

Öğrencilerin "And" adlı eserde dikkatlerini çeken durumlara ilişkin görüşleri

\begin{tabular}{lcc}
\hline Öğrenci görüşleri & $f$ & $\%$ \\
\hline Kan içme & 14 & 29,79 \\
Mıstık'ın ölümü & 11 & 23,40 \\
Kolunu kesme & 10 & 21,28 \\
Hayati tehlike & 5 & 10,64 \\
Köpeğin önüne atlama & 3 & 6,38 \\
Ant içme & 2 & 4,26 \\
Köpeğin dövülmesi & 2 & 4,26 \\
\hline Toplam & 52 & 100 \\
\hline
\end{tabular}

Tablo 2'de, öğrencilerin en çok dikkatlerini çeken olayın ne olduğu görülmektedir. Öğrencilerin cevaplarından hareketle; kan içme $(\% 29,79)$, Mıstık'ın ölümü $(\% 23,40)$, kolunu kesme $(\% 21,28)$, hayati tehlike $(\% 10,64)$, köpeğin önüne atlama $(\% 6,38)$, ant içme $(\% 4,26)$, köpeğin dövülmesi $(\% 4,26)$ şeklinde yedi alt kategori elde edilmiştir. Katılımcıların ifadelerine bakıldığında onları en çok etkileyen olayların kan içme sahnesi, Mıstık'ın ölümü ve kol kesme gibi kitaptaki şiddet içeren bölümler olduğu görülmektedir. Yani öğrenciler kitabı okuduktan sonra dikkatlerini çeken yerlerin çoğunlukla şiddet içeren sahneler olması, eserin bu yaş düzeyindeki öğrencilerin psikolojik ve kişilik gelişimleri açısından sakıncalı olabileceği düşüncesini doğurmaktadır. Konu hakkında bazı öğrencilerin görüşleri bu bulguyu destekler niteliktedir:

En çok dikkatimi çeken olay budur. Ilk önce kollarını kesip sonra kanını içmeleri (Ö5).

Onların and içmeleri, yani kan içmeleri ilk defa böyle bir şey duydum (Ö9).

Kollarını kesip kan kardeşi olmaları çünkü kollarını kesince hep kan geliyor ve canları acıyor (Ö6).

En çok dikkatimi çeken Mıstık'ın öldüğü olaydı. Çünkü o acı verici bir olaydı (Ö13).

Köpeği dövmeleri ve Mıstık’ın ant içmesi dikkatimi çekti (Ö18).

En çok dikkatimi çeken şey Mıstıkın kendini köpeğin önüne atması (Ö22).

Dikkatimi çeken bir olay Mıstık' ın bir kişsinin önüne geçiyor kendi hayatını tehlikeye atıyor (Ö8).

Öğrencilerin eserde dikkatlerini en çok çeken olaylar göz önüne alındığında, şiddet içeren olayların ön plana çıktığı görülmektedir. Öğrencilerin aklına direkt bu olayların gelmesi, kitabın en dikkat çeken kısımlarının şiddet içerdiği şeklinde yorumlanabilir.

Eserde öğrencilerin istemediği ve hoşlarına gitmeyen olayların ne olduğunu belirlemek için "Kitapta değiştirmek istediğiniz yer var mı? Varsa neyi değiştirmek isterdiniz?" soruları sorulmuştur. Bu doğrultuda öğrencilerin verdiği cevaplar Tablo 3'e aktarılmıştır.

Tablo 3.

Öğrencilerin "And" adlı eserde değiştirmek istekleri olaylara ilişkin görüşleri

\begin{tabular}{lcc}
\hline Öğrenci görüşleri & $f$ & $\%$ \\
\hline Mıstık'ın ölmesi & 15 & 31,25 \\
Köpek saldırısı & 12 & 25,00 \\
Kol kesilmesi & 10 & 20,83 \\
Kan içilmesi & 7 & 14,58
\end{tabular}




\begin{tabular}{lll} 
Kan kardeş olma & 4 & 8,33 \\
\hline Toplam & 48 & 100 \\
\hline
\end{tabular}

Tablo 3 incelendiğinde, öğrencilerin eserde değiştirmek istedikleri bölümlerle ilgili beş farklı kategori oluştuğu görülmektedir. Bunlar: Mıstık'ın ölümü $(\% 31,25)$, köpek saldırısı $(\% 25,00)$, kol kesilmesi $(\% 20,83)$, kan içilmesi $(\% 14,58)$, kan kardeş olma $(\% 8,33)$ şeklinde sıralanabilir. Elde edilen kategorilere bakıldığında, öğrencilerin eserde değiştirmek istedikleri olayların en başında olayın kahramanı Mıstık'ın ölümü yer almaktadır. Bu durumun öğrencileri fazlasıyla etkilediği söylenebilir. Ayrıca öğrencilerin büyük çoğunluğu, Mıstık'ın ölümüne neden olan köpek saldırısını da değiştirmek istemektedirler. Diğer kategoriler göz önüne alındığında öğrenciler, kendilerine korkutucu gelen ve sürekli iğrendiklerini belirttikleri kol kesme, kan içme ve kan kardeş olma şekillerini değiştirme eğilimindedirler. Bu bağlamda bazı öğrencilerin görüşleri şu şekildedir:

Mıstık' ın öldüğü yer ve köpeğin saldırmasını değiştirirdim (Ö7).

Mıstık' ın bir kişiyle kan kardeşi olmasını ve Mıstık' ın ölmesini değiştirmek isterdim, kuduz köpeğin Mıstık' ın önüne atılmasını değiştirmek isterdim (Ö8).

Ben bu öyküde köpeğin Mıstık’ı ısırdığı ve öldürdügü olayı değiştirmek isterdim. Beni etkiledi (Ö13).

Bu öyküde beğenmediğim ve değiş̧tirmek istediğim şudur: çoban köpeğinin Mıstık'a saldırdığı yeri değiştirmek isterdim (Ö4).

Kan kardeş oldukları yeri, kollarını kestikleri yeri değiştirmek isterdim. Bu bana hiç hoş gelmedi (Ö19).

Öğrencilerin görüşlerine bakıldığında kitapta değiştirilmek istenen yerlerin şiddet içerdiği, öğrencilerde hüzün, korku ve karamsarlık gibi olumsuz duyguları ön plana çıkardığı ve bunun sonucunda öğrencilerin bu bölümleri istemedikleri görülebilmektedir.

Eserde çocukların kan kardeşi olma şekillerinin öğrencilerde bıraktığı etkiyi anlamak için onlara "Okuduğun öyküde çocukların kan kardeşi olma şekilleri hakkındaki görüşlerin nelerdir?" sorusu sorulmuştur. Bu doğrultuda öğrencilerin verdiği cevaplar kategorilere ayrılarak Tablo 4'e yansıtılmıştır.

Tablo 4.

Öğrencilerin, eserde yer alan kan kardeşi olma olayı hakkındaki görüşleri

\begin{tabular}{lcc}
\hline Öğrenci görüşleri & $\mathrm{f}$ & $\%$ \\
\hline Kötü & 14 & 24,56 \\
İğrenç & 13 & 22,81 \\
Korkutucu & 9 & 15,79 \\
Saçma & 8 & 14,04 \\
Uygun değil & 7 & 12,28 \\
Acayip & 6 & 10,53 \\
\hline Toplam & 57 & 100 \\
\hline
\end{tabular}

Tablo 4'te görüldüğü üzere öğrencilerin yukarıdaki soruya verdikleri cevaplardan yola çıkılarak altı kategori oluşturulmuştur. Bunlar; kötü $(\% 24,56)$, iğrenç (\%22,81), korkutucu $(\% 15,79)$, saçma $(\% 14,04)$, uygun değil $(\% 12,28)$, acayip $(\% 10,53)$ şeklinde sıralanabilir. Elde edilen verilere bakıldığında, eserde çocukların kollarını kestikten sonra birbirlerinin kanlarını içerek kan kardeşi olma şekilleri, öğrencilerde olumsuz duygular bırakmıştır. Bu bağlamda bazı öğrencilerin görüşleri şu şekildedir:

Kötü bir şey bu. Yapmazdım çünkü çok kötü (Ö10).

Çocukların kan kardeş olmaları saçma, iğrenç ve çok kötü geldi. Ben böyle bir şey yapmazdım (Ö11).

Hiç hoşlanmadım güzel bir davranış değil iğrenç ve korkutucuydu (Ö14).

Ben öyle bir şey yapmazdım, ben ne birisinin kanını içerim ve izin vermem kanımı içsin. Ben çocukların bu davranışını hiç beğenmedim. Yaptıkları davranışlar da hiç uygun bir davranış değil (Ö3). 
Ben onların kollarını kesip başka kişiyle birlikte kanlarını karıştırıp içmeleri benim hiç hoşuma gitmedi. Onların bu şekilde kan kardeş olmaları korkutucu. Ben olsam böyle bir şey yapmazdım. Başkalarının kanını içmek hiç hoşuma gitmezdi (Ö4).

Ben öyle yapmazdım. Çocukların kollarını kesmeleri de acayip geldi çünkü boş yere kol kesip kan aktırıp içiyorlar. Bana değişik geldi. (Ö6).

Eserde şiddet ve olumsuz duygular içeren yerlerin öğrencileri etkilediği görülmektedir. Özellikle öğrencilerin kendilerini kötü hissedecek kadar etkilendikleri olayların yer aldığı bölümlerin, kitap okunduktan sonra onlarda duygusal örselenmelere yol açabileceği düşünülmektedir.

Eserde Mıstık'a kuduz bir köpeğin saldırması ve bunun sonucunda Mıstık'ın ölmesinin öğrenciler üzerinde bıraktığı etkiyi anlamak için "Okuduğun öyküde köpeğin Mıstık'a saldırması ve sonrasında Mıstık'ın ölmesi hakkındaki görüşlerin nelerdir? Bu bölümü okuduktan sonra neler düşündün?" sorusu sorulmuştur. Bu doğrultuda öğrencilerin verdikleri cevaplar kategorilere ayrılarak Tablo 5'e yansıtılmıştır.

Tablo 5.

Öğrencilerin Mıstık’ın ölüm şekliyle ilgili görüşleri

\begin{tabular}{lcc}
\hline Öğrenci görüşleri & $f$ & $\%$ \\
\hline Kötü hissettim & 15 & 34,88 \\
Üzüldüm & 11 & 25,58 \\
Acl verici & 7 & 16,28 \\
Hoşuma gitmedi & 6 & 13,95 \\
Korktum & 4 & 9,30 \\
\hline Toplam & 48 & 100 \\
\hline
\end{tabular}

Tablodan da anlaşılacağı üzere öğrencilerin verdikleri cevaplardan hareketle; kötü hissetim $(\% 34,88)$, üzüldüm $(\% 25,58)$, acı verici $(\% 16,28)$, hoşuma gitmedi $(\% 13,95)$, korktum $(\% 9,30)$ şeklinde beş kategori oluşturulmuştur. Elde edilen kategorilere bakıldığında, Mıstık'ın ölüm şeklinin öğrencilerde kötü his, üzülme, korku gibi çeşitli olumsuz duygular bıraktığı görülmektedir. Bu bağlamda bazı öğrencilerin görüşleri şu şekildedir:

Çok ama çok kötü düşünüyorum. Bu bölümü okuduktan sonra çok kötü hissettim (Ö1).

Ben çok üzüldüm onun ölmesine, keşke Mıstık kaçıp saklansaydı ve onun ölmesini hiç istemezdim (Ö3).

Köpeğin Mıstık'ı ısırması ve daha sonra ölmesi hiç hoşuma gitmedi. Mıstık'ın çok iyi biri olduğunu düşünüyorum ben bu bölümü dinledikten sonra çok üzüldüm ve kendimi kötü hissettim (Ö5).

Acı verici bir olay olduğunu düşünüyorum. Bu bölümü dinledikten sonra kendimi kötü hissettim (Ö13).

Bence acı ama gerçek bir şey keşke Mıstık ölmeseydi (Ö20).

Eserde geçen ve öğrencileri derinden etkileyen olayların başında hiç şüphesiz Mıstık'ın ölümü ve ölüm şekli gelmektedir. Özellikle eserin sevilen kahramanı Mıstık'ın kuduz bir köpek tarafından öldürülmesini öğrenciler büyük üzüntüyle karşılamıştır. Ayrıca öğrencilerin bu ölüm şeklinden duydukları rahatsızlığı olumsuz duygularla ifade ettikleri görülmektedir.

Eserde Mıstık'ı öldüren köpeğin bazı adamlarca kovalanması ve dövülmesinin öğrenciler üzerinde bıraktığı etkiyi anlamak için "Okuduğun öyküde iki adamın sopalarla köpeği kovalamaları ve Mıstık'ı ısıran köpeği döverek oradan uzaklaşmaları hakkında ne düşünüyorsun? Sence bu doğru mu?" sorusu sorulmuştur. Bu doğrultuda öğrencilerin verdikleri cevaplardan hareketle Tablo 6 oluşturulmuştur.

Tablo 6.

Öğrencilerin, köpeğin kovalanması ve dövülmesiyle ilgili görüşleri

Öğrenci görüşleri $f$

f $\%$




\begin{tabular}{lcc}
\hline Doğru değil & 16 & 45,71 \\
Hayvana şiddet & 9 & 25,71 \\
Üzüldüm & 7 & 20,00 \\
İyi yaptılar & 3 & 8,57 \\
\hline Toplam & 35 & 100 \\
\hline
\end{tabular}

Öğrencilerin verdikleri cevaplardan yola çıkılarak dört farklı kategori oluşturulmuştur. Bunlar; doğru değil $(\% 45,71)$, hayvana şiddet $(\% 25,71)$, üzüldüm $(\% 20,00)$, iyi yaptılar $(\% 8,57)$, şeklinde sıralanabilir. Elde edilen kategorilere yönelik bazı öğrenci görüşleri şu şekildedir:

Hayır, böyle bir şey doğru değil, bununla ilgili çok kötü düşünüyorum. Insan asla ama asla bir hayvana zarar vermemeli (Ö1).

iki adam köpeği kovaladıkları için köpek korkmuş ve Mıstık'ı ısırmış Mıstık da ölmüş. Bence bu çok yanlış. Eğer köpek kovalanmasaydı kimseyi ısırmazdı (Ö3).

Kötü bir şey, doğru değil. Çünkü o da canlı. (Ö10).

Bu doğru değil hayvanlara şiddet uygulamamalıyız (Ö16).

Bence bu köpeğe böyle yapmamaları gerekir hiç doğru değil hayvana şiddet uyguladılar (Ö17).

Bence çok iyi bir şey yaptılar ama zamanında yetişselerdi o zaman Mıstık ölmeyecekti Mıstık'la kan kardeşi bir kişi olacaktı (Ö8).

Yukarıdaki cevaplara bakıldığında, öğrencilerin tamamına yakını tarafından hayvanın kovalanmasının ve dövülmesinin doğru bir davranış olmadığı ifade edilmiştir. Ayrıca, öğrencilerin bir kısmı yapılan davranışın hayvana şiddet olduğunu belirterek kitaptaki bu olaya dikkat çekmişlerdir. Ancak bazı öğrenciler ise köpeğin dövülmesini doğru bulduklarını çünkü köpeğin Mıstık'ın ölmesine neden olduğunu ifade etmişlerdir.

Kitabın kapağındaki resmin öğrencilere neler hissettirdiğini belirlemek amacıyla öğrencilere “Öykünün kapağındaki resim hakkında neler düşünüyorsun? Resmi yorumlar mısın?" sorusu sorulmuştur. Bu doğrultuda öğrencilerin verdiği cevaplardan yola çıkılarak Tablo 7 oluşturulmuştur.

Tablo 7.

Öğrencilerin "And" adlı kitabın kapağındaki resimle ilgili görüşleri

\begin{tabular}{lcc}
\hline Öğrenci görüşleri & $f$ & $\%$ \\
\hline Korku verici & 13 & 43,33 \\
Beğenmedim & 9 & 30,00 \\
Üzücü & 6 & 20,00 \\
Güzel & 2 & 6,67 \\
\hline Toplam & 35 & 100 \\
\hline
\end{tabular}

Tablo 7 incelendiğinde, öğrencilerin verdikleri cevaplardan hareketle dört farklı kategori oluşturulduğu görülmektedir. Bunlar; korku verici $(\% 43,33)$, beğenmedim $(\% 30,00)$, üzücü $(\% 20,00)$, güzel $(\% 6,67)$ kategorileridir. Konuyla ilgili bazı öğrenci görüşleri şu şekildedir:

Resmin kapağı korku vericiydi. Çünkü Bir tane köpek çocuğu arkadan kovalıyor. Arkadan iki adam da sopayla onu dövüyor (Ö1).

Iyi çizilmiş ama kapakta adamın köpeği sopayla kovalaması çok kötü ve korkunç (Ö10).

Bence sonları anlatıyor ve ben beğenmedim güzel değildi (Ö3).

Bence biraz alakalı biraz da üzücü (Öو).

Bence kapak çok güzel, bir çocuk kaçıyor arkasından köpek çocuğu kovalıyor, köpeğin arkasından bir adam sopayla köpeği kovalıyor (Ö16).

Yukarıdaki cevaplara bakıldığında, öğrencilerin kitabın kapağındaki resim hakkındaki görüşleri de diğer temalarda olduğu gibi olumsuz duygular içermektedir. Özellikle kapak resminin şiddet ve korku içeren ögeler barındırmasının, öğrencilerin kapaktan etkilendiklerini gösteren ifadeler kullanmalarına neden olduğu söylenebilir. 


\section{Tartışma ve Sonuç}

Çocuk kitaplarında yer verilen olayların, durumların, duygu ve düşüncelerin çocuğun psikolojik ve kişilik gelişimini olumlu veya olumsuz anlamda etkilediği bilinmektedir. Özellikle çocuğa okutulacak kitapların belli yaş gruplarına ayrılması ve içerikleri göz önünde bulundurularak okutulması önemlidir. Çünkü çocuğun, okuduğu kitaptan etkilenme veya çıkarımda bulunma yaşı ilk çocukluktan yetişkinliğe kadar farklılaşmaktadır. Bu nedenle çocuklara okutulacak kitaplarda şiddet, korku, ölüm, engellilik, aşırı duygusallık gibi çocuk okurda travmaya yol açabilecek konuların yoğun bir şekilde yer alması çocuğun psikolojik, kişisel, sosyal vb. birçok yönden gelişimini olumsuz şekilde etkileyebilmektedir. Bu bağlamda, özellikle çocuklara okutulacak kitapların yaş düzeylerinin doğru belirlenmesinin öğrencilerin gelişimsel özelliği bakımından önem arz ettiği bilinmelidir.

Ömer Seyfettin'in kaleme aldığı öykülerin büyük bir kısmı yazıldığı dönemde meydana gelen olaylardan izler taşımakta, o dönemin sorunlarını yansıtmaktadır. "And" adlı eserin de toplumsal olaylardan ve dönemin şartlarından etkilenilerek yazıldığı söylenebilir.

$\mathrm{Bu}$ araştırmada; eserde yer alan şiddet olgusunun katılımcılar tarafından nasıl algılandığını ortaya çıkarmak amacıyla öğrenci görüşleri alınmış, öyküde yer alan şiddet sahnelerinin öğrenciler tarafından nasıl algılandığı ve bu sahneler hakkında neler düşündükleri belirlenmeye çalışılmıştır. Bu bağlamda, araştırmanın dikkat çekici sonuçlarından bir tanesi, öğrencilerin kitapta şiddet içeren yerlerle ilgili sürekli olarak "korkunç, üzücü, acıklı, kötü, iğrenç" gibi ifadeleri kullanmalarıdır. Bu durum kitapta geçen olayların öğrenciler üzerinde olumsuz bir etki oluşturduğu, öğrencilerin kitabı okumak istemedikleri, kitapta geçen bazı olayların onların kendilerini kötü hissetmelerine neden olduğu sonucunu doğurmaktadır. Ayrıca öğrencileri etkileyen en önemli olayların "ölüm, kan, dövme, şiddet, kan kardeşliği" gibi durumlar olduğu ve bunun sonucunda öğrencilerde "korku, kötü his, acı, hüzün, beğenmeme, iğrenme, uygun görmeme" gibi duygular oluştuğu söylenebilir. Kitapta geçen olaylar hakkındaki öğrenci görüşleri göz önüne alındığında, And adlı eserin 6. sınıf seviyesindeki öğrencilere okutulmaması gerektiği düşünülmektedir.

Elde edilen verilerden ve yukarıda bahsi geçen sonuçlardan hareketle şunlar söylenebilir: Öğrencilerin çok büyük bir kısmının şiddet sahneleri nedeniyle öyküyü beğenmemeleri Yıldız (2009)'ın çalışmasıyla örtüşmektedir. Yıldız, Ilköğretim Öğrencilerinin Çocuk Kitaplarına iliş̧kin Görüşleri adlı yüksek lisans çalışmasında ilköğretim öğrencilerinin çoğunluğunun şiddet içeren kitapları beğenmediklerini tespit etmiştir. Kayman (2020) da 5. Sınıf öğrencilerinin Ömer Seyfettin'in şiddet içeren eserlerine verdikleri tepkileri incelediği çalışmasında katılımcıların çoğunluğunun bu eserleri beğenmediği sonucuna ulaşmıştır. Çocuk edebiyatının en önemli amacının çocuğa okuma sevgisi ve alışkanlığı kazandırmak olduğu (Sever, 2008: 19) göz önüne alınacak olursa çocukları sevdikleri ve beğendikleri eserlerle bir araya getirmek büyük önem taşımaktadır. Zira çocuklar kitaplarda kendilerinden bir şeyler bulurlarsa ve onu beğenirlerse okurlar (Bülbül, 1960).

Eserde katılımcıların en fazla dikkatlerini çeken şeyin kolun kesilmesi, Mıstık'ın köpek tarafından ısırılarak ölmesi, köpeğin dövülmesi gibi şiddet içeren vakalar olduğu görülmektedir. Zira bu yaş grubundaki (10-11 yaş) çocukların şiddet konusunda oldukça hassas bir dönemde olmaları ve şiddetten kolayca etkilenebilmeleri (Yavuzer, 1987), eseri okurken dikkatlerinin bu vakalara yönelmelerine yol açmış olabilir. Bu noktadan hareketle şiddet içeren çocuk kitapları, hitap ettiği yaş grubu göz önünde bulundurularak hazırlanmalı ve bu kitaplarda yer alan şiddetin sunuluş biçimine dikkat edilmelidir (Çiftçi, 2013; Sever, 2002: 36).

Çalışma grubundaki öğrencilerin önemli bir kısmı, kurguda değişiklik yapma tasarrufunun kendilerinde olması durumunda eserde yer alan şiddet sahnelerini değiştirmek istediklerini ifade etmişlerdir. Kayman (2020), yaptığı çalışmada öğrencilere okuduğu şiddet içerikli tüm eserlere öğrencilerin aynı tepkiyi verdiklerini, onların şiddet sahnelerini eserin dışına çıkarmak istediklerini tespit etmiştir. Bu durum, eserin trajik yapısından kaynaklanmış olabilir. Zira bulgular kısmında görüldüğü üzere Mıstık'ın köpek tarafından ısırıldıktan sonra kuduz olup ölmesi, diğer taraftan birkaç kişinin köpeği sopayla dövmesi öğrencilerin duygusal anlamda etkilenmelerine neden olmuş ve yaşanan bu trajik olaylar onların ifadelerine de yansımıştır. Bu yaş grubundaki çocukların kolay etkilenme döneminde olmaları (Yavuzer, 1987), onları şiddet içeren sahneler karşısında böyle bir düşünceye sevk etmiş görünmektedir. 
Eserde yer alan kan kardeşi olmak için bilek kesme ve kan içme sahneleri öğrenciler tarafından yadırganmış ve bu durum kötü, iğrenç, korkutucu, saçma, uygun değil gibi ifadelerle dile getirilmiştir. Eski bir Türk geleneği olan kan kardeşliği için ant içme bazı yörelerde hâlâ yetişkinler ve belli bir yaş grubundaki çocuklar arasında yapılmaya devam etmektedir (Durmuş, 2009: 106). Bu araştırmada çalışma grubunda yer alan öğrencilerin bu durumu beğenmedikleri ve uygun bulmadıkları görülmüştür. $\mathrm{Bu}$ durum, öğrencilerin etkilenme düzeylerini ortaya koyması ve bu yaş grubundaki çocuklara okutulacak eserlerin tespiti bakımından önemli görülmektedir.

Eserde Mıstık'ın köpek tarafından ısırıldıktan sonra kuduz olması ve ölmesi öğrencilerin üzülmelerine, kendilerini kötü hissetmelerine, korkmalarına neden olmuştur. Bütün öğrencilerin bu sahneden hoşlanmadıkları görülmektedir. Mıstık'ın köpek tarafından şiddete maruz kaldıktan sonra ısırılarak ölmesi öğrencileri etkilemiş, onları rahatsız etmiştir. Bu durumun onların benzer tepkiler vermelerine yol açtığı söylenebilir. Şiddet sonucunda meydana gelen ölümlerin travma yarattığı (Bildik, 2013) göz önüne alındığında öğrencilerin bu tepkilerini anlamak mümkün olmaktadır. Öztürk (2017) de çalışmasında, öğrencilerin şiddet sonucunda gerçekleşen ölüme benzer tepkiler verdiğini, bu tür bir ölümden hoşlanmadıklarını ortaya koymuştur. Fakat Öztürk'ün çalışmasında bu tepki daha çok öfke şeklinde ortaya çıkmıştır.

Eserde hayvanın (köpeğin) kovalandıktan sonra sopalarla dövülmesi öğrencilerin tamamına yakını tarafından doğru bulunmamıştır. Bu sonuçlar Kayman (2020)'ın sonuçlarıyla örtüşmektedir. Kayman, çalışmasında hayvanların şiddete maruz kaldığı esere karşı öğrencilerin çoğunluğunun şiddetten kaçış tepkisi verdiklerini, eserde yer alan bu şiddetten hoşlanmadıklarını tespit etmiştir. Çocuk eserlerinde çocuğun duygu dünyasına seslenen konular onların sağlıklı bir gelişim göstermeleri bakımından önemlidir. Bu nedenle çocukların gelişim dönemleri dikkate alınarak konu seçimi yapılmalı(Şahin ve Bayramoğlu, 2016); korku, şiddet, ölüm, engellilik gibi olguların yer aldığı eserler uygun yaş grubundaki okurlara okutulmalıdır.

And adlı öykünün kapağında yer alan resimde bir köpeğin bir çocuğu hışımla kovaladığı, çocuğun korkarak kaçtığı görülmektedir. Öğrencilerin büyük bir kısmının bu resmi beğenmedikleri; resim hakkında korku verici, beğenmedim, üzücü gibi ifadeler kullandıkları görülmüştür. Çocuk kitaplarındaki kapak resimlerinin ve iç kısımlarda yer alan resimlerin çocukların yaşına, gelişimine, ilgi ve ihtiyaçlarına uygun olması gerekmektedir. Bunun yanında bu resimler ve kitabın içeriği çocuk okuru korkutmamalıdır (MacNaughton ve Williams, 2004). Çalışma grubundaki öğrencilerin ifadelerine bakılacak olursa kapak resmi çocuğa hitap etmemekte ve onda olumsuz duyguların oluşmasına yol açmaktadır. Bu durum göz önünde bulundurulmalı, çocuk kitaplarında yer alan resimlerin onların hayatını etkileme gücüne sahip olduğu (Karagöz, 2018), düşünce ve davranışlarında kalıcı bir etki bırakabileceği (Şirin, 2000) unutulmamalıdır.

\section{Araştırma ve Yayın Etiği}

Bu çalışmada "Yükseköğretim Kurumları Bilimsel Araştırma ve Yayın Etiği Yönergesi" kapsamında uyulması belirtilen tüm kurallara uyulmuştur. Yönergenin ikinci bölümü olan "Bilimsel Araştırma ve Yayın Etiğine Aykırı Eylemler" başlığı altında belirtilen eylemlerden hiçbiri gerçekleştirilmemiştir. Çalışmada öğrenci velilerinden izin alınmış, onlara bilgilendirilmiş gönüllü olur/onam formu imzalatılmıştır.

\section{Etik Kurul İzni}

Kurul adı = Van ili Tuşba İlçe Milli Eğitim Müdürlüğü

Karar tarihi $=06 / 01 / 2021$

Belge sayı numarası $=18856386$

\section{Yazarların Katkı Oranı}

Bu çalışmaya 1. yazar tarafından \%50, 2. yazar tarafından \%50 oranında katkı sağlanmıştır.

\section{Çıkar Çatışması}

Bu çalışmada çıkar çatışması teşkil edebilecek herhangi bir durum yoktur. 


\section{Kaynaklar}

Akkaya, N. (2003). Ömer Seyfettin'in "Bomba" adlı öyküsündeki şiddet unsurları. Çocuk Edebiyatına ve Çocuk Hekimliğine Yansıyan Şiddet Sempozyumu içinde (s. 47-51). Eskişehir: Osmangazi Üniversitesi.

Aktaş, E. ve Uzuner Yurt, S. (2017). Çocuk edebiyatı açısından Ömer Seyfettin'in hikâyelerinde çocuğa göre olmayan unsurlar. International Online Journal of Educational Sciences, 9(1), 207-223.

Bildik, T. (2013). Ölüm, kayıp, yas ve patolojik yas. Ege Tıp Dergisi, 52(4).

Bölükbaş, F. (2003). Beyaz Lale öyküsünün şiddet-çocuk psikolojisi bağlamında değerlendirilmesi. Çocuk Edebiyatına ve Çocuk Hekimliğine Yansıyan şiddet Sempozyumu içinde (s. 65-70). Eskişehir: Osmangazi Üniversitesi.

Bülbül, S. (1960). Çocuk ve kitap (1). Türk Kütüphaneciliği, 9(3-4), 111-114.

Büyükkavas Kuran, Ş. ve Ersözlü, Z. N. (2009). Sınıf öğretmenlerinin çocuk edebiyatına ilişkin görüşleri. Yüzüncü Yıl Üniversitesi Eğitim Fakültesi Dergisi, 6(1), 1-17.

Büyüköztürk, Ş., Kılıç Çakmak, Akgün, Ö. E., Karadeniz, Ş. ve Demirel, F. (2016). Bilimsel araştırma yöntemleri. Ankara: PegemA Yayıncılık.

Cengiz, G. (05-07 Ekim 2011). Ömer Seyfettin öykülerinin çocuğa görelik ilkesine göre incelenmesi ve bu öykülerdeki ötekileştirme ve şiddet öğelerine bakış. III. Ulusal Çocuk ve Gençlik Edebiyatı Sempozyumu'nda sunulan bildiri, Ankara Üniversitesi, Ankara.

Creswell, J. W. (2017). Araştırma deseni: Nitel, nicel ve karma yöntem yaklaşımları. (Çev. Edt. Selçuk Beşir Demir), Ankara: Eğiten Kitap.

Çer, E. (2014). Edebiyatta çocuk gerçekliği ve çocuğa görelik ilkelerinin incelenmesi (Yayımlanmamış doktora tezi). Ankara Üniversitesi Eğitim Bilimleri Enstitüsü, Ankara.

Çiftçi, F. (2013). Çocuk edebiyatında yaş gruplarına göre kitaplar ve özellikleri. Anemon Muş Alpars/an Üniversitesi Sosyal Bilimler Dergisi, 1(1), 125-137.

Dağlığlu, H. E. ve Çamlıbel Çakmak, Ö. (2009). Okul öncesi çocuklarına yönelik yayınlanan hikâye kitaplarının şiddet ve korku öğeleri açısından incelenmesi. Türk Kütüphaneciliği Dergisi, 23(3), 510-534.

Dilidüzgün, S. (1996). Çağdaş çocuk yazını (1. Baskı). İstanbul: Yapı Kredi Yayınları.

Dilidüzgün, S. (2003). Iletişim odaklı Türkçe derslerinde çocuk kitapları. İstanbul: Morpa Kültür Yayınları.

Durmuş, i. (2009). Türk kültür çevresinde ant. Millî Folklor, 84, 97-106.

Erdal, K. (2009). Eğitim değerleri ve çocuk kitapları. Akademik Bakış, 17, 1-18.

Fırat, H. (2014). Ömer Seyfettin'in fıkra kaynaklı hikâyelerinde din ve ahlakî değerler. Cumhuriyet International Journal of Education, 3(3), 12-24.

Fırat, H. ve Çeker, S. (2016). Çocuk kitaplarında dilin şiddet aracı olarak kullanımı. Türkiye Sosyal Araştırmalar Dergisi, Özel Sayı, 83-107.

İsen-Durmuş, T. I. (2011). Klasik eserlere çocuklar nasıl yönlendirilmeli ve buna ilişkin batıdaki uygulamalardan örnekler. Electronic Turkish Studies, 6(3), 929-937.

Karagöz, B. (2018). Resimli çocuk kitaplarında gözden kaçan bir alan: ileti problemi (Anne Tavuk Anlatıyor serisi örneği). Electronic Journal of Social Sciences, 17(68), 1765-1787.

Kayman, F. (2020). Kurgusal metinlerde şiddet olgusuyla karşılaşan beşinci sınıf öğrencilerinin Ömer Seyfettin öyküleri bağlamında şiddeti algılamaları üzerine bir araştırma (Yayımlanmamış doktora tezi). Atatürk Üniversitesi Eğitim Bilimleri Enstitüsü, Erzurum.

Köksal, Ü. (1997). Çocuk tiyatrosunun özellikleri ve tiyatro dili. Ana Dili Eğitimi ve Çocuk Kitapları Sempozyumunda sunulan sözlü bildiri, Ankara.

MacNaughton, G. ve Williams, G. (2004). Teaching young children, choices in theory and practice. Pearson Education Australia

Miles, M. B. ve Huberman, A. M. (1994). Qualitative data analysis: an expanded sourcebook. California: Sage Publications.

Moustakis, C. (1982). A plea for heads: illustrating violence in fairy tales. Children's Literature Association Quarterly (7)2, 26-30.

Neydim, N. (2003). Çocuk edebiyatı. İstanbul: Bu Yayınevi. 
Nimon, M. (1993). Violence in children's literature today [microform] / Maureen Nimon Distributed by ERICClearinghouse,[Washington,D.C.] http://www.eric.ed.gov/contentdelivery/servlet/ERICSe rvlet?accno=ED399935

Ömer Seyfettin. (2014). And. İstanbul: Karanfil Yayınları.

Öztürk, H. (2017). Çocuk edebiyatında ölüm teması (Okur merkezli bir araştırma) (Yayımlanmamış doktora tezi). Atatürk Üniversitesi Eğitim Bilimleri Enstitüsü, Erzurum.

Oğuzkan, F. (2006). Çocuk edebiyatı. Ankara: Anı Yayıncılık.

Öztürk, M. ve Giren, S. (2016). Okulöncesi dönemdeki çocuklar için hazırlanan hikâye kitaplarındaki korku ve şiddet öğelerinin incelenmesi. Ulus/ararası Türkçe Edebiyat Kültür Eğitim Dergisi, 5(4), 2095-2108.

Sever, S. (2002). Çocuk kitaplarına yansıtılan şiddet (Milli Eğitim Temel Yasası ve Çocuk Haklarına Dair Sözleşme bağlamında bir değerlendirme). Ankara Üniversitesi Eğitim Bilimleri Fakültesi Dergisi, 35(1), 25-37.

Sever, S. (2008), Çocuk ve edebiyat. İzmir: Tudem Yayınları

Şahin, D. ve Bayramoğlu, C. D. (2016). 2015 Türkçe öğretim programının metin tür ve tema seçimi bakımından değerlendirilmesi. Turkish Studies (Elektronik), 11(3), 2095-2130.

Şirin, M. R. (1998). 99 soruda çocuk edebiyatı. İstanbul: Çocuk Vakfı Yayınları.

Şirin, M. R. (2000). Çocuk edebiyatı. İstanbul: Çocuk Vakıf Yayınları.

Şirin, M. R. (2007). Çocuk edebiyatı kültürü. Okuma alışkanlığı ve medya sarmalı. Ankara: Kök Yayıncılık.

Tosunoğlu, M., Haktanır, G., Çocuk, H. E. ve Gök, Z. (2008, Mart). Illköğretim ikinci kademe öğrencilerine göre Ömer Seyfettin. II. Dünden Bugüne Ömer Seyfettin Sempozyumu'nda sunulan sözlü bildiri, Balıkesir.

Turan, L. (2006). Violence and death in stories of war period writer Ömer Seyfettin, ERIC Digest, ED493901 p.28.

Uçan, H. (2005). Çocuk kadar saf, temiz olabilmek/kalabilmek. Hece, Çocuk Edebiyatı Özel Sayısı, 104105.

Yalçın, A. ve Aytaş, G. (2008). Çocuk edebiyatı. Ankara: Akçağ Yayınları.

Yavuzer, H. (1987). Çocuk psikolojisi (3. Baskı). İstanbul: Remzi Kitabevi.

Yıldırım, A. ve Şimşek, H. (2016). Sosyal bilimlerde nitel araştırma yöntemleri (6.Baskı). Ankara: Seçkin Yayıncılık.

Yıldız, Ç. (2009). Illköğretim öğrencilerinin çocuk kitaplarına ilişkin görüşleri (Yayımlanmamış yüksek lisans tezi). Anadolu Üniversitesi Eğitim Bilimleri Enstitüsü, Eskişehir.

Yılmaz, O. ve Yakar, Y. M. (2018). Türk çocuk edebiyatında sorun odaklı yaklaşım. Çocuk ve Medeniyet Dergisi, 3(6), 29-42.

Yılmaz, O. (2016). Çocuk kitaplarında bulunması gereken özellikler. T. Şimşek (Ed.), Okul öncesinde çocuk edebiyatı ve medya içinde (1. Baskı, ss. 61-108). Ankara: Grafiker Yayınları.

Yurttaş, H. (1997). Çocuk ve kitap. Ana Dili Eğitimi ve Çocuk Kitapları Sempozyumunda sunulan sözlü bildiri, Ankara.

\section{Introduction}

\section{Extended Abstract}

When works in domestic and foreign literature are examined, it becomes apparent that one of the frequently discussed topics included in children's books is violence. There are two different perspectives on the issue. Those who defend the first view think that there should be no elements of violence in children's books and consider violent expressions as a risk for child readers (Dağlıoğlu and Çamlıbel Çakmak, 2009; Öztürk and Giren, 2016; Yalçın and Aytaş, 2008). According to the other view, the phenomenon of violence may be included in children's books, like other traumatic subjects, provided the sanity of the child reader is not jeopardized because of the way violence is presented.

The purpose of this study was to determine the opinions of middle school $6^{\text {th }}$ grade students about the parts of Ömer Seyfettin's story "And" which contains violence. It sought to answer the question, What do middle school $6^{\text {th }}$ grade students think about the scenes of violence in Ömer Seyfettin's story "And"? 


\section{Method}

The study is qualitative by design; it employed phenomenology. A total of $226^{\text {th }}$ grade students, 10 girls and 12 boys, participated in the study. A semi-structured interview form prepared by the researchers was used to determine the opinions of the students, and the opinions of two expert faculty members were sought to determine whether the questions in the interview form fit for the research goals. In the research, content analysis, a qualitative data analysis method, was used to analyze the data obtained through the semi-structured interview forms.

\section{Result and Discussion}

In this study, students' opinions were obtained to understand how the phenomenon of violence revealed in the scenes of violence in the story was perceived by $6^{\text {th }}$ grade students. A striking finding was that the students constantly used expressions such as "terrible, sad, bad, disgusting" about the parts that contained violence in the book. This finding leads to the conclusion that the violence in the book creates a negative perception on the students towards the story, that the students did not want to read the book, and that some events in the story caused them to feel bad. In addition, the events that affected the students were death, blood, beating, violence, and blood brotherhood. Those events caused students to experience emotions of fear, pain, sadness, dislike, disgust, and disapproval. Considering the effects of the events on the students, it was concluded that the story should not be used for teaching $6^{\text {th }}$ grade students. Based on the findings, it can be said that most of the students did not like the story because majority of the students did not like books that contained violence as stated by Yıldız (2009). Kayman (2020) also concluded that $5^{\text {th }}$ grade students did not like the violence included in Ömer Seyfettin's works. Considering that the most important goal in having children read works of children's literature is to have students like reading and instill a sustained reading habit in them (Sever, 2008: 19), it is of great importance to introduce children to works in which they will find something from themselves so that they will like and read them (Bülbül, 1960). 